\title{
Cyberbullying on Students’ Blog: Exploring Bully in Digital Era
}

\author{
Budianto Hamuddin ${ }^{1}$, Syahdan $^{2}$, Latifah $^{3}$ Kurniawan $^{4}$, and Bayu Febriadi ${ }^{5}$ \\ ${ }^{1,2,3,4}$ Dept of. English Education, FKIP. Universitas Lancang Kuning \\ ${ }^{5}$ Dept of. Information System, Fasilkom. Universitas Lancang Kuning \\ budihamuddin@gmail.com
}

\begin{abstract}
EFL students interactive communication somehow an exciting topic to discuss. Seeing foreign language speakers interact and communicate with each other on the internet, this is an interesting linguistic study for review. This present library study tries to explore ten high recognized papers from contemporary studies regarding cyberbullying among students' interactive communication. From these ten studies, this ongoing study constructs its perspective in seeing the cyberbullying context. This study uses a library study in qualitative approach and explores ten contemporary research about cyberbullying and came out with a result of present perspective and currently proposed terminology of cyberbullying among EFL bloggers.
\end{abstract}

Keywords: Cyberbullying, Blog, ELT

\section{BACKGROUND}

The possibility to have a learning process anywhere, anytime and with anyone around the globe seems finally come true with the help of information technology (IT) nowadays. The touch of information technology through online Teaching process becomes a new trend for everyone meet in the virtual class or online interaction. Using a blog in the teaching process is one of the IT revolutionary to help everyone including lecturers and students in the e-learning teaching process [1], [5].
For many years blog has been proven as a suitable tool to teach many subjects including foreign language such as English in lower or higher educational institutions. It seems like an alternative learning media in this global era, where everybody was connecting digitally blog enriching the area of English language teaching. The research conducted by Noytim's 2010; Gutler, 2011, Aydan, 2014; Hamuddin, et al., 2018 believed blog offers various advantages to simplify the learning process in effective ways. The findings in this study were revealed the uniqueness and significant 
contributions of the blog and in the end recommending a blog as an alternative media in teaching English in higher education. The raising trend of blogging interactive activities between students around the globe increasing significantly since many a decade ago. The data in the study above revealed that blog regarding English Language Teaching (ELT) process was not only functioned "as a students journal but used as a tool to improve the skill in English, especially writing" [6].

However, these studies also discussed and recommended the effectiveness of blog's usage in English language teaching (henceforth: ELT), they also remind that there are several obstacles in the process which might ruin the process as well as a result.

The idea letting blog helping ELT practitioners around the globe even though was proven raising the motivation to learn English [5] or also even gives maximum benefit to the teachers, lecturers of English, in many educational institutions around the globe.[1], [2], [3], [6] but every practitioner should aware of several things that can make ruin it including cyberbullying [6].

One of many impacts of cyber culture is the tendencies to give free space to everybody posting opinion or content that might hurt, bother, or making the other people feeling threatened or uncomfortable. The fact showing that blog can be that "perfect area" to train their ability in writing their journal but it also can transform as a conflict zone with the cyberbullying issues [6].

According to Merriam-Webstar dictionary, cyberbullying means "the form of "threat" or "attack" by someone to someone else sent through the electronic messages or media." Similarly, in the Cambridge dictionary, it mentions that cyberbullying is an "activity of using the internet to harm or frighten another person, especially by sending them an unpleasant message." There have been many research from psychological, criminological, IT or other fields like education or sociology that explains the symbolic violence regarding cyberbullying on virtual life that it was sometimes even worse than the physical attack in real life for the victim. The term "cyberbullying was initially a convenient label for abusive behavior perpetrated through the use of mobile telephones and computers with Internet access" that describes cyberbullying as an effort to make fun of or an effort to embarrassed of someone else through their communication gadgets during the online session [6]. Moreover, Corcoran, L., Mc Guckin, C., Prentice, G. (2015), in their article reminds us "... that there is potential for wide public access to online content, a single cyberbullying incident could have a serious and lasting harmful effect on the victimized person". 
The short-term negative impact of cyberbullying is the worry, fear, uncomfortable, loneliness, depression, and low score academically. Furthermore, cyberbullying in the virtual world could bring uncomfortably, remove the confidence, attract depression, extreme worry, introvert effect, decreasing score, and might be the cause of some suicide attempt. Therefore, this symbolic attack in the context of cyberbullying becomes a scary thing to everyone using the advance technology [7].

Thus, if this happens in the educational institution, it might ruin the learning process, especially who use a blog as its classroom framework such as at PBIG-FKIP Unilak. Therefore, in their research, Hamuddin, et al., (2017, p.19) reminds the challenge beyond it "... the use of blog has given a massive impact in the learning process at PBIG FKIP Unilak, but then every new thing will have its own risk and challenge" that should be faced by the lecturers, students, and faculty together. However, in his latest research Hamuddin, et al. (2018) mentioned ".. the phenomena of cyberbullying among English students of PBIG Unilak who interact and communicate in the internet is also an interesting linguistic topic to be analyzed, on how these students of English as a foreign language trying to express their "feeling" and "thoughts" through blog as well as training their skill in writing into their blog to be something productive.
Therefore, these study would like to extend their standpoints by continuing their investigation and digging deeply concerning the students, motives and responds as well as present definitions towards cyberbullying will be a perfect hub for this study to enhance its perspective. Further, this ongoing study is trying to explore deep the phenomena of students, the motive as well as redefining the cyberbullying terminology among EFL students at PBIG.

\section{METHOD}

Ten contemporary selected studies regarding cyberbullying issues around the globe were chosen to share its perspective on cyberbullying. This library research on a qualitative study in nature tries to explain "cyberbullying" among EFL students at PBIG FKIP Unilak. Library research defined as the systematic study and investigation where conclusions are based on the analysis of data collected under pre-established research designs and methodologies.

However, this study limits its discussions only on the review literature and theory to overcome and explain the phenomena and proposed a correct terminology of cyberbullying among the EFL students. The analysis in this study based its data limits its data only ten present studies on in this part. Beyond its limitations, this ongoing study would like 
to contribute to the pool of knowledge on what is cyberbullying in the EFL context.

\section{FINDINGS AND DISCUSSION}

\subsection{Cyberbullying: The definitions}

Many studies about cyberbullying have conducted around the globe from the various disciplines such as Sociology, Psychology, IT, Criminology, and Education. Aune, 2009; Rivers \& Noret, 2007; Lakitta et al., 2016; Slonje, 2011; Hinduja \& Patchin, 2010; also Salus, 2012. These are some researchers that have been referred a lot to the discussion regarding cyberbullying as its topic. These studies might have their definitions and see cyberbullying based on their discipline and background. However, they seem to agree on each other that cyberbullying seen as the forms of threat and harassment where there is a psychologist forced to someone people who are "weaker" by someone or a group of people who use the sophisticated information technology.

The same thinking also mentioned by Utami, Y.C. (2014), which described cyberbullying as a "form of harassment faced by the children or teenagers by people around their age, or their peers through the virtual or cyber world or as we call it, the internet." The form of harassment in the form of nick-namecalling, shaming, intimidating, or being disrespected by the other children or teenagers through IT technologies.
Furthermore, Teasley, M (2013) in his study, stressed the phrase "to harm others" showing that people should be more cautious regarding cyberbullying. As he mentioned:

“... Cyberbullying has been defined as the use of information and communication technologies to support deliberate, repeated, and hostile behavior by an individual or group that is intended to harm others. It involves the use of electronic communication devices to engage in text messaging, internet usage, and other digital forms of communication". [15].

Teasley, M (2013)

Many others definition which came from the ten selected studies in this ongoing research, however, it is quite the same as the definitions and views above. Meanwhile, a slightly different perspective coming from Hamuddin et al. (2018) who study cyberbullying among EFL students. In their study, they revealed that the cyberbullying phenomenon as "only an intention of playing with language as well as a language exaggeration from EFL students with their self-esteem resolutions when interacting on the online framework with their limited knowledge of English." This study quite unique by seeing from the subject in the study which involved 157 EFL students from Indonesia that might the culture is quite different with 
some part of the world, especially in western culture. Therefore, this study saw a cyberbullying is an act using threat language which intended to attack victims psychological side using the online framework such as social media sites or chatting applications. This online interactive activity is designed to harm others or not, depends on the motives as well as who are the victims and the offender.

\subsection{Cyberbullying: The Motives}

The form and method of cyberbullying are high in diversity, so is the motive beyond the person committing the cyberbullying itself. Patchin \& Hinduja (2010) came up with "The teenagers committing cyberbullying are the teens with the authoritarian personality, and they have the needs to rule and control others. These teens only prioritize themselves compared to others, and they often label the others as the unimportant". Furthermore, the article published by Patchin \& Hinduja (2010) also explains that "... someone committing cyberbullying has the tendencies having low self-esteem". Beside the low selfesteem issue, Kowalski, Limber (2013) in the article tends to see the issues "psychological health, physical health and academic performance" to cause someone to become the victim of bullying.

The other issue affects according to Hinduja \& Patchin (2013) in cyberbullying is the impact of peers their age or conformity. In that article, they reveal that "These teenagers in their growing phase, getting impacted a lot by their environment, especially family and friends at school. Along with the development process of the children to be teenagers, these peers having a higher impact to form their attitude and behavior". The next issues are the transition phase of teens or a psychosocial moratorium from children who need guidance, to the adulthood where their teens age starting in touch with some responsibilities (Santrock; 2012). In this phase, society and parents tend to give limited freedom to experiment and finding their image, and causing the identity crisis happens, or Santrock (2012) refers to identity confusion.

Moreover, Slonje (2011) and Salus (2012) in their writing also talk about motives that make someone committing cyberbullying, namely:

a) Mad, revenge, heartache, or frustration.

b) Showing their ego then hurts others (hunger for power).

c) Seek for entertainment and to be able to laugh and get the response.

d) Unintentional, such as reaction/ impulsive and emotional comment

e) Feeling bored (at the same time) having the ability of hacking

However, if we were reflecting on the context of cyberbullying among EFL 
students in their online interaction in their blogs. A slightly different motive can be found that not all the cyberbullying motives indicated to harm others [7]. Hamuddin et al. (2018) analyzing. 157 blogs run by 21 male bloggers and 136 female bloggers revealed three biggest motives revealed in this present study was only designed just for fun (74\%), fight back act $(9 \%)$ and expressing pique $(5 \%)$. What the thing needs to consider is the motive, i.e., just for fun is the highest percentage. It means in the context of EFL students blogging interaction; they are not really intended to harm someone. Therefore, this study saw a cyberbullying motive it might not all intended to harm others. it depends on the motives or the treatment as well as who are the victims and the offender as well.

\subsection{Cyberbullying: The Types}

Cyberbullying allows the conventional bully to commit this easily since they are face to face with their target. They could use threatening words and intimidate phrase to their victim easily because they are behind the computer screen or cell phone without having to witness the effect they have on the victim. (Slonje, 2011). There are many forms and methods of cyberbullying in the virtual world, it could be in the form of threatening, creating a site to spread rumors, uploading photos, mentioning something embarrassing or pictures that put the victim to shame, and writing post to have a laugh about the victim even to access their social network to threat the victim and create a problem. In general, the dissertation written by Slonje (2011), it mentioned six main types of cyberbullying, namely:

1) Flaming: "A provocative act, mocking, or even insulting that hurt others that create a massive debate."

2) Online Harassment: "Sending numerous messages or terrorizing the other person with hurtful messages that could harm others through the online media."

3) Outing: "Sending personal data such as pictures, videos, or even the victim's text to insult the victim."

4) Denigration : "Sending the invalid message or extreme denigration about someone to someone else, or sharing the photos or videos online, for an example like a teen, sending a gossip on their social network (intentionally) so there will be a misunderstanding between the victim and the friends, or even to dismiss the friendship itself".

5) Masquerade: "Disturbing others by using a fake identity in bullying, for example, a teen using someone else's profile to attack his or her victim so they will not be able to figure out the actor."

6) Exclusion: "Excluding someone from an online group or forum, like when a teen is not being involved in a group 
chat because her friends do not fancy her."

Furthermore, Salus (2012) slightly in line with the types mentioned in the dissertation wrote by Slonje (2011) revealing the types of cyberbullying by using different terms but somewhat the same in actions such as; Bombing, slandering, flaming, impersonation (hacking), defamation, deliberately, and happy slapping. In some of these types of cyberbullying, the difference might only at the bombing type which means inviting others to "mock" intensively, also happy slapping which means "tricking" or spreading the "product" too embarrassed the victim. Therefore, these research sees cyberbullying in general as a form of bullying committed by offenders on the internet as media, or digital technology by sending or spreading a hateful message, mocking to intimidate, insult or to make them uncomfortable in the virtual life.

However, when its discussed cyberbullying types in EFL blogger context. The types are the same, only the motive beyond the act was entirely different [6], [16]. Hamuddin et al. revealed that there are several common types of cyberbullying in the blogging interactive communication among EFL students. Means that, not all types of cyberbullying above referring to Slonje (2011) or Salus (2012) can be found in the context of EFL students' blogging online activity. Hamuddin, et al. (2018) only managed to find out four similar types of cyberbullying with the above types. Further, from 157 blogs he analyzed Hamuddin, et al., only manage to the discover 255 statements that can be indicated as cyberbullying. The types were; flaming (69\%), harassment (25\%), slandering (4\%) and name-calling (3\%).

There are various ways in which cyberbullies offender attack and threaten their victims, i.e., with the help of social networking websites, text messaging and phone calls to cell phones. There are different forms of cyberbullying including, but not limited to, the types mentioned above. However, It has been found that there are differences between not only the pervasiveness of cyberbullying between males and females but also the habits [1]. Nevertheless, The main findings from the study conducted in Slonje (2011) showed that cyberbullying and conventional bullying were very much inter-linked, usually cyberbullying started from a face-to-face interaction or the opposite, conventional bullying usually started from a cyber context. Therefore, this study realized that somehow the existence types of cyberbullying depend on the context or settings of the interactive communication.

\section{CONCLUSIONS}

The touch of sophisticated technology information in the blog makes the media more variative, creative, and innovative in 
giving a massive impact on the learning process including in ELT context. This study saw a cyberbullying is an act using threat language which intended to attack victims psychological side using online frameworks such as social media sites or chatting applications. This online interactive activity is designed to harm others or not, depends on the motives as well as who are the victims and the offender. Likewise, the motives of this study seen a cyberbullying motives it might not all intended to harm others. It also depends on the motives or the treatment as well as who are the victims and the offender as well. In many cases cyberbullying we can see as an act to hurt or to make other embarrassed. However, in EFL blogging context, it seems this type of cyberbullying is quite different. The act that in their online interaction was more to "express themselves" as well as "playing with their English" through writing although, the comment might offensive or indicated as cyberbullying. Moreover, the phenomenon of cyberbullying in the students' interactive online interaction it might be serious matter, however, it is not a thing to be feared in high frequency but merely on something to be observed and solve it.

\section{REFERENCES}

Aune, N.M. 2009. "Cyberbullying." Master's Thesis. University of Wisconsin-Staut

Aydin, Selami. 2014. "The Use of Blogs in Learning English as a Foreign Language". Mevlana International Journal of Education (MIJE). 4(1): 244-259.

Corcoran, L., Guckin, C. M., \& Prentice, G. (2015). "Cyberbullying or cyber aggression?: A review of existing definitions of cyber-based peer-topeer aggression". Societies, 5(2), 245-255.

Fageeh, A.I. 2011."EFL Learners' Use of Blogging for Developing Writing Skills and Enhancing Attitudes Towards English Learning: An exploratory study". Journal of Language and Literature. 2 (1): 3148.

Hamuddin, B. (2016). "Using blog to Promote English Skills for EFL Students: The Students' Perception". ELT-Lectura Journal. 3 (2): $1-8$.

Hamuddin, B., Kurniawan, K., Syaifullah, S., \& Herdi, H. (2018). Detecting Major Problems in Learning English Through Blog-based Class. Journal of Education and Learning (EduLearn), 12(3).

Hinduja S, Patchin JW. (2013). "Social influences on cyberbullying behaviors among middle and high school students". J Youth Adolesc.;42(5):711-722. 
Hungerford-Kresser, H., Wiggins, J., \& Amaro-Jimenez, C. 2012.” Learning from Our Mistakes: What matters when incorporating blogging in the content area literacy classroom". Journal of Adolescent \& Adult Literacy. 55 (4): 326-335.

Johnson, L. D., Haralson, A., Batts, S., Brown, E., Collins, C., Van BurenTravis, A., \& Spencer, M. Cyberbullying on Social Media Among College Students.

Kowalski, R.M., Limber, S.P., \& Agatston, P.W. (2008). Cyberbullying: Bullying in the digital age. Oxford: Blackwell Publishing.

Noytim, Usa. 2010. "Weblogs Enhancing EFL Students' English Language Learning". Procedia - Social and Behavioral Sciences. Volume 2, Issue 2, hal. 1127-1132.

Özdemir, Emrah, Selami Aydın. 2015. "The Effects of Blogging on EFL Writing Achievement". The Proceedings of the 1st GlobELT Conference on Teaching and Learning English as an Additional Language., Balikesir: Balikesir University

Salus, C., 2012. "CYBER BULLYING: a new age of bullying amongst adolescents and what educators can do about it". Master's thesis. Winona State University

Slonje, R., (2011). "The nature of cyberbullying in Swedish schools: Processes, feelings of remorse by bullies, impact on victims and age and gender differences". Doctoral dissertation. University of London

Teasley, M. (2013). "Cyberbullying, youth behavior, and society". Journal of Child and Adolescent Behaviour, 2, 120. doi: 10.4172/2375-4494.1000119

Utami, Y. C. (2014). “Cyberbullying di Kalangan Remaja: Studi Tentang Korban Cyberbullying di Kalangan Remaja di Surabaya”. Doctoral dissertation, Universitas Airlangga. 